\title{
Gyógyítók és gyógyítás a folklór és orvostörténet tükrében a Meiji elötti Japánban
}

\section{Bevezetés}

Jelen tanulmány célja a gyógyítás történetének áttekintése Japánban a hagyományos világnézet, népi kultusz, majd a hivatalos orvoslás fejlődésének tanulmányozásán keresztül. A választott téma annyira tág, hogy természetesen itt ennek a folyamatnak csak a fontosabb mérföldkőit és jelentősebb példáit tudjuk bemutatni.

A hivatalos orvoslás megjelenéséig, és azután is, számos mód állt a rendelkezésére annak, aki gyógyulni vagy a betegséget megelőzni szerette volna. A gyógyítás fizikai szinten való megközelítése mellett a spirituális megközelítés is ugyanannyira, vagy akár még fontosabb is volt, hiszen a megbetegedést sokáig felsőbb erők hatásának is tulajdonították. Ennek a szemléletnek az érvényessége még a mai modern ipari japán társadalomban is fennáll. Számos tanulmány bizonyítja, hogy a japánok egészséghez és betegségekhez való viszonyát jelentősen meghatározza egyfajta holisztikus világnézet. A klasszikus modern gyógyászat mellett ma is virágoznak a különféle spirituális tanácsadások, és napjainkban is sokan fordulnak a sintó és buddhista gyógyító istenek felé. Itt említhetjük meg továbbá azokat a Meiji-korban felbukkanó és gomba módra szaporodó új vallási szektákat is, amelyek többségére jellemző, hogy a szellemvilágnak tulajdonítanak minden megbetegedést. Ezért is gyakori az, hogy egy-egy szekta teljesen elutasítja a klasszikus modern gyógyászatot és annak módszereit.

A Meiji-kor elött azonban még inkább igaz volt az, hogy a betegségeket egyrészt az istenek kommunikációjának vélték, másrészt a gyógyításhoz különféle médiumokhoz fordultak annak reményében, hogy a betegséget okozó istenséget, szellemet kibékíthetik, illetve a gyógyuláshoz a segítségét kérhetik. Az orvosréteg fokozatos kialakulásával párhuzamosan tehát a különféle népi gyógyítók, kuruzslók, médiumok mindvégig részei voltak a társadalomnak, és folyamatosan végezték különböző gyógyító tevékenységüket. Ezek között 
találjuk a sámán-hagyományt folytató mikokat 巫女 és itakokat いたこ, vagy a shugendo 修験道 szerzeteseit, akik közvetítöként müködtek, és a szellemi világot hívták segítségül a gyógyításhoz. Mindennek megértéséhez azonban szükséges megvizsgálni azt a világnézetet és életszemléletet, amely meghatározta a japán ember hozzáállását a betegségekhez.

A betegség szorosan kapcsolódik a mulandóság témájához, és a világ vallásai, a különféle népek hitvilágai mind különféleképpen tekintenek a mulandóság, a betegség, és a gyógyítás kérdéskörére. Tanulmányunk első felében ezért a japánok és a betegség viszonyát fogjuk röviden áttekinteni, továbbá azt, hogy melyek azok az elemek a japán hagyományos világnézetben, amelyek ezt a viszonyt a legjelentősebben befolyásolták. Ezután, a teljesség igénye nélkül, megvizsgálunk néhány olyan szereplőt, akinek a szerepkörébe tartozott a gyógyítás. Másrészt bemutatunk néhány olyan istenséget, amelynek gyógyító képességet tulajdonítottak. A tanulmány másik felében a Nara-kortól kezdve kialakuló hivatalos orvostörténet mérföldkőit fogjuk górcső alá venni a fennmaradt fontosabb történelmi források és tanulmányok alapján.

\section{Betegség, halál, és gyógyítás a hagyományos világnézetben}

A közhelynek számító mondat, mely szerint „az orvostudomány története az emberiség fejlödésével azonos korú", alapjában véve igazat mond, hiszen a gyógyászat megjelenése előtt minden népnek - ahogy a japánnak is - természetesen már jóval korábbról voltak elképzelései arról, mi okozhatja a betegséget, és hogyan kellene azt kezelni.

A legkorábbi időszakokban nagy valószínúséggel a gyógyítás a halál elleni küzdelem eszközeként a spirituális módszereket üzők, vagyis a varázslók és sámánok feladata volt. Japánnal kapcsolatban erről már a legkorábbi írásos forrásokban találunk utalásokat. Ilyen például a Gishi Wajinden 魏志倭人伝 című kínai klasszikus, amely érintőlegesen foglalkozik a japánok hitvilágával, és a jóslás és varázslás is megjelenik a leírásokban. ${ }^{1}$ Hasonlóan fontos forrásnak számít a Kojiki 古事記, a Nihonshoki 日本書紀 vagy az Engi-shikiben 延喜式 található norito 祝詞 liturgikus szövegek, amelyekböl információkat szerezhetünk arról, hogy milyen is volt a korai Japánban létező hitvilág, hogyan tekintettek a japánok a világra és az életre. Az itt leírtakból már követ-

$1 \quad$ Shinmura et al. 2006: 18. 
keztethetünk azokra a fontosabb hiedelmekre, amelyek meghatározták a japánok betegségről alkotott nézeteit. Itt kerülnek először leírásra olyan fogalmak, mint például a rituális tisztaság és tisztátalanság, amelynek központi jelentősége van a japán kultúrában, és máig hatással van a japánok gondolkodására, értékrendszerére, kapcsolatrendszereire. Ahogy azt számos kutató alátámasztotta, a tisztaság és tisztátalanság kettős elve nem egyszerüen a sintó kultusz központi eszméje, hanem általában véve a japán világnézet rendszerező elve is. A Kojikiben megjelenő történetek és mítoszok ennek az első írásos lenyomatai, de valószínüsíthető, hogy a dokumentum csak megfogalmazott már sokkal régebb óta létező és érvényesnek hitt hiedelmeket, valamint szabályokat.

A tisztaság és tisztátalanság kapcsolata és ennek vonatkozásai máig befolyásolják azt, hogyan tekintenek a japánok testre, egészségre, gyógyításra, betegségre, és nem utolsósorban a halálra. A fent említett régi dokumentumokban a tisztátalanság mint a legfőbb rossz, többek közt minden betegség okozójaként jelenik meg. A tisztaság és tisztátalanság kettőssége fontos eleme a mitológiai történeteknek, amelyek az istenségek megszületését mesélik el. Ezek közül is emeljük ki a japán panteon legfontosabb istene, a napistennő Amaterasu történetét, aki testvérével, Susano-oval, Izanagi isten „mosakodásából" keletkezik. Izanagi mosakodni kényszerül, mivel tisztátalanná vált halott felesége, Izanami megpillantása által. A mosakodás lényegében egy purifikációs rítust jelenít itt meg. A vízzel való lemosás, öblítés máig az egyik legfontosabb purifikációs eszköz, és a kézmosás és szájöblítés a sintó szentélyek megközelítése alapetikettjének része, egyúttal a hétköznapi higiénia elengedhetetlen eleme is. Az utcai piszok, szenny, de ezzel együtt a betegséget okozó bacilusok bejutását a házba nem csak az utcai lábbeli levetésével akadályozzák meg. Elsősorban a kézmosás és gyakran szájöblítés biztosítja, hogy a külső világ szennyezettsége ne veszélyeztesse az otthon „tiszta” világát. A higiéniának erre az alapvető szabályára már kora kisgyerekkortól tanítják a japán gyerekeket a szüleik, gondozóik. ${ }^{2}$ Ohnuki-Tierney, aki behatóan tanulmányozta a japánok betegséghez való viszonyát a jelenkori Japánban, a baktériumokat és bacilusokat a japán pszichében egyértelmüen a soto 外 (külső tér) világába helyezi, ahol is ez szorosan kapcsolódik a tisztátalan, piszkos minőséghez. ${ }^{3}$ Ez a külső, az otthonon (uchi 内) kívül elhelyezkedő tér

2 A japán gyereknevelésben megjelenő tisztaság és tisztátalanság képzetek elemzését lásd többek közt Joy Hendry munkájában (Hendry 1986).

Ohnuki-Tierney 1984: 22-25. 
fenyegeti közvetlenül és szimbolikusan is a tisztasággal összekapcsolt minőséget, így az egészséget is. ${ }^{4}$ A fizikai és szimbolikus így egymást lefedi és erősíti.

Visszatérve a Kojikihez, az élet és halál, illetve a tisztaság és tisztátalanság kettősségének párhuzama már itt világosan kirajzolódik. Eszerint a tisztátalanságot okozó tényezők között a halál egyértelmüen a legsúlyosabb, de szorosan követik ezt a menstruáció, szülés, terhesség, abortusz, húsfogyasztás, és nem utolsó sorban a betegség. Az állathússal való érintkezés, továbbá az állatbörrel való munkálatok is mind rituális szennyezettséget okoztak az érintettek számára, és ezek fontos alapjai lettek a társadalmi kirekesztettség legitimációjának, lásd a burakumin 部落民 problémát. ${ }^{5}$ Habár a halál, halottal való érintkezés számítottak a legsúlyosabb tisztátalanságot okozó tényezőknek, a vérrel való kapcsolat is egyértelmúen tisztátalanságot okozott, ahogy az a gyermekszülésnél is jól látható. Tisztátlansági tabuknak vetették alá a szülő anyát és gyermekét is, de számos helyen a szülő nő közvetlen családtagjai, néha az egész közösség is érintettek voltak. Erre számos példa található a népi hiedelmekben és szokásokban. ${ }^{6}$ Szülőkunyhók (ubukoya 産小屋) megtalálhatók voltak egészen az 1950-es évekig Japán egyes részein, s általában a falu határán, vagy egy folyó, patak partján helyezkedtek el. ${ }^{7}$ A funkciójuk lényegében az volt, hogy megakadályozzák a tisztátalanság terjedését, amelyről úgy vélték, ragályos is lehet. A szülő nő itt töltötte a vajúdás óráit, majd gyermekével együtt az első napokat is. ${ }^{8}$ A nőkre általában szigorúbb tisztátalansági szabályok vonatkoztak, mint a férfiakra, hiszen az ő létük többször került kapcsolatba a vérrel. Ilyenkor (szülés, menstruáció, abortusz) nem vehettek részt sintó rítusokban, közösségi ünnepeken, ahogyan a sintó szentélyekbe sem léphettek. A szülés után legalább 30 napnak kellett eltelnie ahhoz, hogy a tisztátalanság ,enyhüljön”, és anya és gyermeke visszatérhessen megszokott

4 A rituális tisztaság és tisztátalanság elméleti keretét a hare-kegare-ke kategóriák hármas struktúrájaként is megjeleníti a szakirodalom. A hare áll a legközelebb a spirituálisan és erkölcsileg tiszta állapothoz, a ke jellemzi a mindennapok profán állapotát, miközben a kegare mindaz, ami tisztátalan, szennyezett, nem elfogadott, vagy bármi, ami eltér a normálistól. Lásd a témában magyar nyelven Papp 2018, továbbá Akata 1979: 90-93 és Namihira 2009.

5 Történelmileg az állatbőrt feldolgozó mesterségeket űző embereket és családjaikat diszkrimináció érte, a többségi társadalmon belül külön csoportot alkottak (lásd a témában Csendom 2014).

6 A témáról magyar nyelven lásd Papp 2013.

7 Matsuoka 2003: 20-25.

8 Lásd a témában Itabashi 2007: 288-291. 
életrendjéhez. A megtisztulási időszak végét az imiake 忌明け jelezte, amikor is a gyermeket a család női tagjai elvitték bemutatni a helyi védőistenségnek (ujigami 氏神), ami a ma is népszerü miyamairi 宮参り rítus eredete.

Fontos azonban megemlíteni a tisztasághoz kapcsolódó egyéb elképzeléseket is. A tisztaságnak a japán kultúrában nem csak spirituális és fizikai vonzata van, hanem morális, tehát etikai értéket is tulajdonítanak neki. A tisztasággal összekapcsolnak egyfajta jellembeli tisztaságot, mondhatni jellemességet vagy erkölcsi minőséget is. ${ }^{9}$ Ennek megfelelően a betegség az elme tisztátalanságával függ össze, ezért erkölcstelenséget is implikálhat. ${ }^{10}$ Nagyon leegyszerüsítve mondhatjuk azt is, hogy minden, ami tiszta, az jó és helyes. Ugyanakkor a tisztátalant, vagy egyszerủen a piszkosat, egyértelmüen a roszszal, helytelennel, nem erkölcsössel kapcsolja össze a japán gondolkodás. Ebből az összefüggésből fontos következtetések vonhatók le a japánok betegség- és egészségtudatával kapcsolatban, hiszen a tisztáról és szennyezettről alkotott képzeteinknek, mélyen gyökerező hiedelmeinknek lényeges pszichológiai vonatkozásai is vannak.

A betegség, mint a tisztátalanság következményének gondolata, már a fent említett korai dokumentumokban is megjelenik, például a lepra leírásában, amelyet egészen az 1950-es évekig gyógyíthatatlan, ragályos, és emiatt rettegett betegségnek tartottak Japánban, és közvetlenül a tisztátalansággal hoztak összefüggésbe. A második világháborúig a leprásokat elkülönítették és diszkriminálták, családalapításukat akadályozták.

\section{A spirituális gyógyítás fontosabb szereplői}

A következőkben a teljesség igénye nélkül azt tekintjük át, melyek voltak a népi gyógyítás fontosabb szereplői. Fujikawa szerint, mivel a korai időszakokban a japánok a betegségeket az istenségek müvének tekintették, a különféle imádságok, áldozattételek, ráolvasások számítottak az akkori gyógyászat legfőbb módszereinek. ${ }^{11}$ A japán szigeteken, hasonlóan Ázsia más helyeihez,

\footnotetext{
9 Lásd például Lebra 1976 in Kalland 1991.

10 Kalland említi Kawai 1975-ös írására hivatkozva, hogy a japánok hajlamosak úgy tekinteni a fizikai fogyatékra mint az érintett jellemének, morális értékeinek a megnyilvánulására (Kawai 1975 in Kalland 1991) (Hayao Kawai „Egalitarianism in Japanese Education." Japan Echo 11:4, 1975).

11 Fujikawa 1904:17-18.
} 
a sámánoknak, vagy egyéb szellemi világgal közvetítő médium-gyógyítóknak volt kiemelkedő szerepe. ${ }^{12}$ A sámánok által végzett gyógyítási mechanizmussal kapcsolatban az orvostudományi antropológiai kutatások rámutatnak, hogy a samanizmus gyógyító rítusai neurobiológiai alapon müködnek, és az általuk kiváltott fiziológiai és emocionális reakcióknak lehet elsősorban gyógyító hatása. ${ }^{13}$

Japánban már a korai időszakokból fennmaradt források is hírt adnak sámán uralkodónőkről, akik politikai és társadalmi feladataik mellett jóslással és szellemüzéssel is foglalkoztak, és valószínűsíthető, hogy gyógyító tevékenységet is végeztek. A kínai és japán forrásokban szereplő leírásokból arra következtethetünk, hogy a sámán uralkodónőknek tulajdonított spirituális erő fontos szerepet játszott politikai hatalmuk és pozíciójuk legitimációjában. Hagyományuk kontinuitását a kutatók többek közt a későbbi mikok 巫女 figurájában látják. ${ }^{14}$ A miko legismertebb képe a sintó szentélyek papnője, aki különféle szerepeket tölthet be a rituális, purifikációs feladatoktól (yutate 湯立) kezdve, rituális táncok (kagura 神楽) bemutatásán keresztül, egészen a különböző médiumi szerepekig, amelyek célja általában az istenek akaratának közvetítése volt (uranai 占い, takusen 託宣, kuchiyose 口寄せ). Ezek a szerepek azonban a modernizációval jelentősen megváltoztak, és a mikok ma egyszerüen a sintó szentélyek női kisegítő személyzete. Továbbra is segédkezhetnek a szentély papjainak a rituálék elvégzésében, vagy a kagura bemutatásában, de a múltban betöltött spirituális és komplex szerepkört ma már nem töltik be, ahogy az istenek és emberek világa közötti közvetítést, gyógyítást, vagy halottak szellemeivel való kommunikálást sem végeznek ma már. ${ }^{15}$

A mikok hagyományához a történelem során számos egyéb sámán szereplő kapcsolódott, és ezek nevei, funkciói, és az általuk végzett rituálék regio-

12 A sámánok gyógyító tevékenységét a világ számos helyén dokumentálták és tanulmányozták. Lásd például az ázsiai samanizmusról szóló tanulmányokat, többek közt Fairchild 1962, Birtalan 1993, 2006, Hoppál 2006. Japán vonatkozásban lásd Blacker 1975. Hoppál többek közt kiemeli, hogy a gyógyítás a sámánok legfontosabb társadalmi funkciója (Hoppál 2013: 81).

Winkelman 2004 in Hoppál 2013: 80. (Winkelman M.J. 2004. „Shamanism as the Original Neurotheology". Zygon 39:1, 193-217.)

Fairchild 1962: 18-19.

15 A népi kultuszban számos egyéb hagyomány létezik, amely a szellemi világgal való kommunikációt volt hivatott segíteni. Egyes helyeken gyerekek is betölthették a médium szerepét bizonyos rítusok alkalmával, hiszen öket a hiedelem még az istenek világához közelinek tartotta (Miyata 2007: 33-38). A témában lásd továbbá Iijima 1991. 
nálisan is eltértek. Így például az egyik ma is legismertebb sámán figura a Tōhoku régióban az itako, de hasonló szerepet töltenek be az ország más részein az wakaワカ, morikoモリコ, gomisoゴミソ, shugenja 修験者, és yuta ユタ néven ismert figurák is. Nincs módunkban most mindegyikükkel behatóbban foglalkozni, ezért itt csak az itako szerepét fogjuk érinteni.

\section{Itako}

Japánban talán az egyik legjobban dokumentált sámán hagyomány az itakokhoz füzödik, akik Honshū szigetének északi tartományaiban, különösen Aomoriban, máig tevékenykednek. A rítus, ahogy más népek sámánjainál, úgy az itakoknál is fontos eszközként, egyben a gyógyítás legfontosabb módszereként jelenik meg. Az ő esetükben is elmondható, hogy gyógyító tevékenységük elsősorban pszichológiai, pszichiátriai, illetve szociális terápiaként értelmezhető. Az itakok, hasonlóan az egyéb sámán szerepet betöltő gyógyítókhoz, segítő szellemekkel teremtenek kapcsolatot, közvetítenek az istenek és az emberek világa között, és jövőt mondanak. Az itakok segítő szellemei lehetnek sintó és/vagy buddhista istenségek, de akár állatszellemek vagy egyéb szellemi lények is, amelyekkel általában az itako beavatásakor rituális házasságot köt. A legismertebb rituáléjuk a már említett kuchiyose, amelynek célja a segítő szellem, vagy a megszólított halott szelleme szavainak vagy akaratának a közvetítése. ${ }^{16} \mathrm{~A}$ kuchiyose rituálénak több fajtáját is ismerjük, ezek közül a kamikuchi 神 $\square$ az, amikor jellemzően az istenek segítségével gyógyítást is végeznek. ${ }^{17} \mathrm{Az}$ itakok népszerüsége a Meiji-restauráció előtt volt a legjelentősebb, később szerepük jócskán meggyengült, de kis számban ma is tevékenykednek Aomori régióban. Tevékenységük szorosan kapcsolódik az Aomori prefektúrában található Osorezan 恐山 (hegység) köré szerveződő kultuszhoz is. ${ }^{18}$ A holtakkal való kommunikáció, üzeneteik tolmácsolása ma a legfontosabb és legkeresettebb tevékenységeik közé tartozik, és az itakok ma is a helyi Osorezan kultuszhoz füződő fesztiválok elmaradhatatlan részét képezik. Az itakokhoz jellemzően lelki megbetegedésekkel fordulnak, amelyeknél hangsúlyosabban érvényes az a vélekedés, miszerint a betegség a

\footnotetext{
16 Az itakok gyakran használják a rituálék közben az oshirasama vagy oshira kami néven ismert istenség-párt, bábok formájában. A szokás eredete homályos. Fairchild 1962: 100

18 Lásd a témában magyar nyelven Németh 2018.
} 
szellemvilágnak, valamelyik istenségnek vagy elhunyt ős szellemének tulajdonítható. De egyéb fizikai betegségek esetében is fordulhatnak hozzá, tanácsot kérve, melyik orvoshoz forduljon a beteg, milyen orvosságot vagy gyógymódot használjon.

\section{Shugendō hegyi remetéi}

A sámánnők mellett számos más spirituális gyógyítással is foglalkozó hagyomány létezett Japánban. A már említett shugendō 修験道 kultusz Japán szerte elterjedt volt, szerzeteseik aszketikus életet folytató hegyi remeték voltak. Habár hagyományuk elsősorban a hegyek, illetve hegyisten kultuszához kapcsolódik, jelentős mértékben szinkretikus hagyományról van szó, amely nem rendelkezik szigorúan vett saját dogmákkal, rituálékkal. Szinte minden Japánban megtalálható vallásos hagyomány elemei fellelhetők benne, így a samanizmusé is. Ezeket a szerzeteseket a női sámán férfi megfelelőjének is tekintették, erre utal a kannagi megnevezés is (巫, 神なぎ). Shugenja 修験者 szerzetesekhez gyakran fordultak várandós nők, hogy megtudakolják a szülés időpontját, elkerüljék a szülés közben fellépő esetleges komplikációkat, majd később a gyermek megbetegedését is. Az életciklus különböző fázisaiban, de jellemzően az egyik fázisból a másikba való átmenetnél, tehát a kritikusnak tekintett pillanatokban kérték a szerzetesek segítségét. Az általuk végrehajtott rituálék elsősorban az istenekkel való támogató kapcsolat megteremtését célozták, és azoknak az isteneknek kérték a segítségét, amelyeknek különféle egészségmegőrzéssel, gyógyítással kapcsolatos képességeket tulajdonítottak, illetve a hosszú életért felelős isteneknek tartották őket. Ezek között találhatjuk a Gyógyító Buddhát, avagy Yakushi Nyorait 薬師如来, Dainichi Nyorait 大日如来 (a Nap Buddhája), Kanzeon Bosatsut 観世音菩薩 (avagy Kannont 観音), vagy Fudō Myō-ōt (Acala, 不動明王). ${ }^{19}$

Itt szükségesnek találjuk, hogy szót ejtsünk az átmenetekröl, amelyekre a hagyományos életszemlélet veszélyekkel terhes időszakként tekintett. A közösség szempontjából kritikus időszakok voltak ezek, mivel a közösség feladata volt, hogy az egyént új pozíciójában elfogadja, befogadja, társadalmilag elismerje. Az átmenetek azonban az egészségre nézve is kockázatosnak számítottak, ezért különleges figyelemmel kezelték őket. Az életciklus át-

19 A jelenség koreai vonatkozásáról lásd többek közt Mecsi 2017. 
meneteit jelölö rítusok magas száma is ennek a jelenségnek a társadalmi és kulturális jelentőségét bizonyítja. E rítusok egyik fontos célja volt az is, hogy védelmet nyújtsanak a betegségek ellen, hosszú és egészséges életet biztosítsanak. Így például a szerencsétlen évek hiedelméhez kapcsolódó yakudoshi 厄年 éveiben úgy tartották, hogy ekkor az illető jobban ki volt téve a betegségeknek, mint az élet egyéb időszakaiban. Ezért a ma is nagy népszerüségnek örvendö yakudoshi rítusok egyik fontos célja a betegségek elleni spirituális védelem biztosítása. A gyerekkor átmeneteihez is kapcsolódnak hasonló hiedelmek. A népi hit úgy tartotta, hogy a betegségeket okozó gonosz szellemek, erők a kicsi gyerekeket a fejükön keresztül támadják meg, ezért is élt az a szokás, hogy a kicsi gyerekek fejét borotválták, kopaszon tartották. A felnöttek tekintete egyfajta védelmet is biztosított a fiatal gyermeknek abban az életkorban, amikor a legnagyobb volt a betegségek kockázata. A shichigosan 七五三 néven ismertté vált három rítust magába foglaló rítussorozat első rítusa, amelyet két vagy három éves korban ünnepeltek, hagyományos nevén kamioki 髪置き (szó szerint ,hajnövesztés”), ehhez a szokáshoz füződik. ${ }^{20}$ Hasonlóképpen, a betegségek elleni védelmet szolgálta az a szokás is, amely szerint védelmező amulettet varrtak a gyerekek felső ruhájának belső részébe. ${ }^{21}$

\section{Buddha istenségek}

A már említett Buddhák mellett további gyógyító vagy betegségek ellen védelmet nyújtó istenségeket is számon tartott a népi hitvilág. Gyakorta fordultak betegségek esetében, vagy megelőzés céljával, Jizō bódhiszattvához ${ }^{22}$ 地蔵菩薩, amelynek főképpen a XVIII. századtól nőtt meg a népszerüsége. Számos képességet tulajdonítottak neki, ezek között betegségek gyógyításának képességét, várandós nők megsegítését. Ismert bódhiszattva volt Enmei Jizō (延命地蔵), amelyhez a hosszú életért fohászkodtak. ${ }^{23}$

A már említett Yakushi Nyorai, Gyógyító Buddha kultusza a buddhizmus bekerülésével egy időben terjedt el Japánban a VI. század környékén. Népszerüsége ezután gyors növekedésnek indult, a IX. századra már a bosszúálló szellemek elủzését, betegségek meggyógyítását várták el a hozzá intézett fohá-

Papp 2016: 87-102, Papp 2013.

Ōtō 1968: 107.

Szanszkrit: Kșitigarbha.

Fugen Enmei bódhiszattváról bővebben lásd Kiss 2016. 
szoktól. Számtalan megjelenítése maradt fenn az évszázadok során, szobrok, képek formájában. Bal kezében általában egy kisebb méretü tégellyel jelenítik meg, amely az orvosságot vagy gyógyító varázsszert tartalmazza. ${ }^{24}$

\section{Materiális segítség, avagy a hivatalos orvoslás kezdetei}

A spirituális segítség mellett azonban a hivatalos orvoslás is fejlödésnek indult, feltehetőleg már az V. századtól kezdve. A japán orvostörténet áttekintése nem kis feladat, vizsgálatát többféle aspektusból lehet megközelíteni, ezért a jelen tanulmányban kizárólag az általunk legalapvetőbb állomásokat és folyamatokat vesszük sorra, valamint eltekintünk azok részletesebb taglalásától. ${ }^{25}$ Ahogyan a tanulmány első felében is olvashattuk, a japán orvostörténet legkorábbi lépéseiről pontos leírások híján csak feltételezéseink vannak. Egyes tudósok, mint például Fujikawa (1904), vagy Hattori (1981) a Nihonshoki alapján az orvostörténet első jelentősebb eseményei közt említik az V. században Sillából és Koguryoból érkező orvosok történeteit. Hattori kiemeli például, hogy a Nihonshokiban található egy szövegrész, amely arról szól, miként érkezett Japánba Komimachini Kanikibu 金波鎮漢紀武, hogy az akkori császárt kigyógyítsa betegségéből. ${ }^{26}$ Hasonlóan csak feltételezéseink vannak egy Chisō 智聡 nevü, Japánba áttelepülő, Kínából származó személyről, akiről azt állítják, hogy rengeteg orvosi klasszikust és olyan emberi testábrázolásokat hozott magával Japánba, amelyek akupresszúrás pontokat tartalmaztak. ${ }^{27}$

Az előbbiekben érintettük már, hogy a korai időszakokban az emberek a megbetegedést az istenek müvének tekintették, ezért a gyógyulást is az isteneknél keresték. Gyógyszerek alkalmazására valószínűleg csak később került

24 A hozzá fohászkodók gyakran kezükkel megdörzsölik a szobornak azt a részét, amely megfelel a megbetegedett testrésznek, abban a hitben, hogy az így meggyógyul.

A japán orvostudomány történetével kapcsolatban számos átfogó tanulmány született mind japán, mind pedig európai nyelvterületeken, melyek közül ki kell emelni Fujikawa Yū 富士川游 (1865-1940), Ogawa Teizō 小川鼎三 (1901-1984), Inoue Kiyotsune 井上清恒 (1904-1988), Hattori Toshirō 服部敏良 (1906-1992) átfogó munkásságát, mivel a tanulmányaik megkerülhetetlen alapmünek számítanak a tudományterület kutatását illetően. A témában lásd még Wolfgang 2000, Miyanagi 1994, Shinmura 2002, Kosoto 2002, Maki 1999, Ōtsuka 2002.

26 Hattori 1981: 29.

27 NKI 2002: 13. 
sor, mivel eleinte zömében gyógyfüveket használtak külsőleg. ${ }^{28}$ Természetesen ekkor még nem létezett önálló sebészet. Inoue megjegyzi, hogy a sebészeti beavatkozásokat az akupunktúrás orvosok végezték, csak később, a XIII. századtól kezdve jelennek meg olyan írások, amelyekben a geka 外科 (sebészet) mint kifejezés is felbukkan. ${ }^{29}$ Különálló sebészetről értelemszerüen majd a háborús időszakokban beszélhetünk, amikor jelentősen megnövekszik a hadakozás miatt keletkezett sérültek száma, valamint amikor az európai medicina - azon belül is a sebészet - is megveti lábát Japánban. Inoue (1972: 518) ennek kapcsán megemlíti, hogy amikor drasztikusan megnövekedett a sebesültek száma az Ōnin-háborút (1467-1477) követően, nem volt elegendő szakember, aki a sebesülteket ellátta volna, így a harcosok saját maguk kényszerültek arra, hogy megoldásokat próbáljanak találni a sebek kezelésére. ${ }^{30}$ A sebészeten kívül a belgyógyászat, a farmakológia és az anatómia fejlődése is az ezt követő korszakokban válik igazán jelentőssé.

A mai ismereteink alapján elmondhatjuk, hogy a gyógyítás az emberi test alapos feltérképezése, illetve annak alapos ismerete nélkül nem lehet sikeres. Ebből kifolyólag jogosan merülhet fel a kérdés, vajon a korai időszakokban hogyan értelmezték az emberi test felépítését? Feltételezhetjük, hogy az emberi testről az elhunytak tetemei alapján alkottak valamiféle képet, de tudatos vizsgálódásról nincsen írásos bizonyítékunk. Az ősi kínai orvoslás hosszú történetét ismerve joggal feltételezhetjük, hogy valamiféle tetemvizsgálat már a korai időszakokban is létezhetett Kínában. Bárki számára nyilvánvaló, akinek sikerül egy-két kínai klasszikus orvosi írásba ${ }^{31}$ betekintenie, hogy azok ábrázolástechnikáit nem kifejezetten mondhatni realisztikusnak, hasonlóan minden más ábrázolási módhoz ebből a korszakból világszerte. Gondoljunk csak a barlangrajzokra vagy az egyiptomi és görög képi megjelenítésekre. Mivel a boncolási procedúra egészen a XVIII. századig tiltva volt, és konkrét japán nyelvü leírások sem álltak az akkori japánok rendelkezésére, így csak a kínai klasszikusok nyújtottak eligazítást a korai idők japán emberének az egészségről, az emberi test felépítéséről, a különféle betegségekröl.

\footnotetext{
28 Fujikawa 1904: 17-18.

29 Inoue 1972: 517.

30 Inoue 1972-es tanulmányában részletesebben is taglalja a sebészet fejlődését Európában és Japánban.

31 Például Mai Jing: https://rmda.kulib.kyoto-u.ac.jp/item/rb00005300\#?c=0\&m=0\&s $=0 \& \mathrm{cv}=383 \& \mathrm{r}=0 \& \mathrm{xywh}=-5214 \% 2 \mathrm{C}-240 \% 2 \mathrm{C} 16906 \% 2 \mathrm{C} 4800$.
} 
A japán gyógyászat történetét a legjelentősebbnek számító kutatások és alaptanulmányok az általánosságban vett történelmi korszakok szerinti felosztás alapján taglalják végig, azonban jelen tanulmányban - a legkorábbi időszakot figyelmen kívül hagyva - a japán gyógyászat történetét az annak fejlődésére gyakorolt külső hatások alapján, meghatározott három nagyobb periódusra bontva tekintjük át. Még mielőtt ennek részletezésébe fognánk, néhány szót kell ejteni a betegségek megelőzéséröl is. A japán yōjō-elmélet 養生論, amely az ősi kínai yangshengből 養生 ered, illetve annak japán átvételének is mondható, testünk és lelkünk egységét, másképpen fogalmazva annak egészsége táplálását, fenntartását hirdeti. A japán gyógyászattal párhuzamosan, de külön érdemes ezt a témakört kezelni, valamint kutatni, hiszen ennek a filozófiának az egyik legfontosabb tanítása a betegségek megelözésére, az egészséges állapot megtartására fókuszál, vagyis nem a betegségek gyógyítására, hanem azok elkerülésére koncentrál elsősorban, ami a japán tradicionális gyógyászat, vagyis a kanpō 漢方 ${ }^{32}$ orvoslás egyik fontos alappillére.

\section{I. periódus: a klasszikus kínai orvoslás dominanciájának időszaka (VII-XVI. század)}

Az előző szempontok alapján a legelső nagyobb periódusnak a VII. századtól a XVI. századig tartó időszakot tekinthetjük, amely azt a folyamatot foglalja magában, amikor a japán gyógyászat (és itt külön megemlítendő az egészségmegőrzés is) szinte teljes mértékben a kínai gyógyászatra és orvosi elméletekre támaszkodott.

Annak köszönhetően, hogy a kínai kultúra és a buddhizmus a Koreai-félszigeten keresztül, különösen a Sui (i.sz. 589-617) és Tang dinasztia (i.sz. 618-959) idején elkezdett beáramlani Japánba, a japánoknak lehetőségük nyílt megismerni a kontinensen már régóta müködő központosított rendszereket, ennek hatására nemcsak a hivatali rendszer, hanem az egészségügyi intézményrendszer is jelentős változtatáson ment át, valamint az akkori törvénykönyvbe módosítások is bekerültek. ${ }^{33} \mathrm{~A}$ folyamathoz még hozzátartozik az

32 A kanpō-igakuról, vagyis a japán tradicionális gyógyászatról, annak történetéröl, valamint annak alapjait jelentő ősi kínai gyógyászatról a Nihon Tōyōigakkai (ed.) 2002, Kosoto 2002, valamint Ōtsuka 2002 értekezik részletesebben.

33 A Taihō-ritsuryō 大宝律令 rendszer révén az orvosi rendszer is megváltozott. A törvénykönyvben található Ishitsuryō 医疾令szabályozás meghatározta, hogy az orvo- 
is, hogy az orvosképzésben az ősi kínai klasszikusnak számító írásokat kezdték alapműveknek tekinteni. ${ }^{34}$ Ez azt jelenti, hogy olyan orvosi klasszikusokat vettek alapul, mint például a Huangdi Nei Jing, Su Wen, Ling Shu 黄帝内経 素問 霊枢, a Nan Jing 難経, a Mai Jing 脈経, a Shanghan Lun 傷寒論, a Jin Gui Yao Lue 金貴要略, a Zhu Bing Yuan Hou Lun 諸病源候論, vagy a Qian Jin Fang 千金方 stb., amelyekkel számos japán orvosi írásban találkozhatunk. Vannak, amelyekben hivatkoznak rájuk, de léteznek olyanok is, amelyek ezeket átdolgozzák. Japán 987-ben összeállított legelső orvosi írása Tanba no Yasuyori 丹波康頼 (912-995) Ishinpo ${ }^{-35}$ 医心方 címü harminc részes műve jó példa erre. A később született írásoknál már a Ming-dinasztia idején keletkezett kínai klasszikusok is fontos szerepet játszanak. ${ }^{36}$

Mindezek mellett, ahogyan Kína kultúrájával együtt a buddhizmus is gyorsan terjedt Japánban, a buddhista szerzetesek gyakran orvosi tevékenységeket is folytattak. Több irodalmi alkotás is foglalkozik a gyógyítás témájával már a XIII. századtól kezdve. ${ }^{37}$ A Kamakura- és Muromachi-korszakban a Kínával folyó folyamatos kereskedelmi és kulturális tevékenység révén elterjednek a Song-kori orvosi ismeretek és klasszikusok, és a gyógyítók zöme egyre inkább a zen-buddhista szerzetesek köréből kerül ki. ${ }^{38}$ Ennek kapcsán fontos megemlíteni, hogy amikor megjelentek a „hivatásosnak” mondott orvosok, vagyis azok, akik már kizárólag csak gyógyítással foglalkoztak, velük kapcsolatosan számos történet született. Ez a tendencia különösen az Edo-korban válik kiemelkedővé - mai szóval élve divatossá - és a kontár gyógyítók karak-

sok a Tenyakuryō 典薬寮 irányítása alatt gyógymódok szerint legyenek kategóriákba sorolva. Ennek értelmében az oktatást is felosztották témák szerint. (Fujikawa 1904: 45-47, 56, Kosoto 2002: 94, Shinmura 2006: 61). NKI 2002: 13 .

Tanba no Yasuyori eredetileg a Zhu Bing Yuan Hou Lun címü klasszikust több alfejezetre osztotta, valamint a praktikusnak számító gyakorlati részeket kiemelte, így született meg az Ishinpō (Fujikawa 1933: 34).

Erre jó példa Xiong Zongli 熊宗立 (1409-1482) írása, a Yi Shu Da Quan 医書大全, amelyet Japánban először adnak ki nyomtatásban, vagy Li Shizhen 李 時 珍 (15181593) Bencao Gangmu 本 草 綱 目címü átfogó műve, amely alapján számos farmakobotanikai munka is születik. Kaibara Ekiken 貝原益軒 (1630-1714) Yōjōkun 養生訓 címü írásának VII. fejezetében számtalan klasszikus kínai írás nevével és szerzőjével találkozhatunk a korai-Han kortól egészen a Ming-korig bezárólag. (Lásd bővebben Zentai 2013: 48, 196-197).

Shinmura et al. 2006: 41-42.

NKI 2002: 14. 
tere a humoros műfajú írások egyik közkedvelt figurájává válik. ${ }^{39}$ Később az Edo-korban ugyanakkor különválik az orvoslással foglalkozók köre, ugyanis megjelennek olyan konfuciánus tudósok, mint például Nakae Tōju 中江藤樹 (1608-1648), Kaibara Ekiken 貝原益軒 (1630-1714), Ogyū Sorai ${ }^{40}$ 荻生 徂徠 (1666-1728), akik többféle tudományterülettel is foglalkoztak, többek között a gyógyítással is. A juik 儒医, vagyis a konfuciánus orvosok a konfuciánus tanítás mellett a gyógyítással, valamint a betegségek megelőzésével, illetve egészségmegörzéssel elméleti és gyakorlati szinten is foglalkoztak. Filozófiájuk középpontjában a xiao 孝, azaz a szülők, vagy elöljárók iránti feltétel nélküli hủség és jámborság elve állt, amelyre az egész emberi életre, testre és lélekre vonatkozó diszciplínákat építettek fel.

Láthatjuk, hogy az addigi orvostudományt és egészségmegőrzés elvét mindvégig a klasszikus kínai orvoslás dominanciája jellemezte, és ezt számos orvosi és egészségelméleti írás is tanúsítja, amelyek ezekből idéztek, vagy ezek alapján íródtak. Az emberi test szerveinek meghatározásánál is az addig ismert klasszikus kínai írások voltak mérvadóak. Ilyen például Kajiwara Shōzen 梶原性全 Ton'isho ${ }^{41}$ 頓医抄 című munkája (XIII. század), amely szintén a klasszikus kínai orvosi írásokat veszi alapul. A 1759-ben össze-

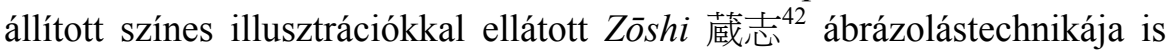
inkább a klasszikus kínai stílust követi még, mintsem az európait. Tehát ebből arra lehet következtetni, hogy ebben a periódusban, sőt, még később is, az emberi testrészek elhelyezkedésére és elnevezésére zömében kínai ábrázolásokat és kifejezéseket ${ }^{43}$ használtak. ${ }^{44}$ Ugyanakkor nem elhanyagolható az sem,

39 Erre jó példa Tomiyama Dōya 富山道冶 (1585-1634), kanazōshi műfajba tartozó Chikusai 竹斎 címü írása.

40 A konfuciánus tudósokról lásd bővebben Szabó 2013 és Szabó 2016.

41 A Sui-dinasztia idején készült kínai klasszikusokat, úgymint Zhu Bing Yuan Hou Lun 諸病源候論, a Tang-dinasztia idejéböl a Qian Jin Fang 千金方, vagy a Song-dinasztia ideje alatt keletkezett Tai Ping Sheng Hui Fang 太平聖惠方, San Yin Fang 三因方, He Ji Ju Fang 和劑局方 stb. klasszikusokat vette alapul, ráadásul a saját tapasztalataival is kiegészítette. 60 kötetes, japán nyelven íródott. (Fujikawa 1933: 48). Yamawaki Tōyō 山脇東洋 (1705-1762) Edo-kori orvos, akinek először engedélyezték, hogy emberi boncolást végezzen el, megfigyeléseinek eredményeit a Zōshi 蔵誌 címü átfogó mủvében jegyezte le. (KJE 1998: 2699).

43 Az elnevezéseket és kifejezéseket japánul a gozō-roppu 五臓六腑 koncepció alapján alkalmazták, erről lásd részletesebben Fujikawa 1933: 25-28.

44 A különféle betegségek ábrázolását tartalmazza a Yamai no sōshi 病草子 emakimono képsorozat, amelyet a Waseda University Library archívumában online megtekinthető: http://archive.wul.waseda.ac.jp/kosho/chi04/chi04_04420/chi04_04420.html. 
hogy ezzel párhuzamosan a köznyelvben léteztek a jamatokotoba ${ }^{45}$ 大和言葉 egyéb változatai a testrészek és a különféle betegségek leírására, csakhogy a későbbiekben inkább a kínai változatok terjedtek el. ${ }^{46}$

A japánok újdonságokhoz való viszonyáról általánosságban elmondhatjuk, hogy nem teljes mértékben átvételt, hanem azt a fajta hozzáállást jelenti, amely az eredetiből megtartja azt, ami számára hasznos, és elveti, amire nincs szüksége ${ }^{47}$ Ez a fajta japanizálódási folyamat például az Edo-kori gondolkodónál, Kaibara Ekikennél is megfigyelhető, aki a gyógyszeradagolás módszerét illetően fogalmazott meg - véleménye szerint - addig még nem ismert újdonságokat, vagy komoly kritikákkal illetett egy korábban megkérdőjelezhetetlenül hitelesnek vélt kínai klasszikust is. ${ }^{48}$ Fontos kiemelni még, hogy ez a fajta japanizálódás a későbbiekben is előfordul, különösen a nagyobb periódusváltások között. Amikor a japán gyógyászaton belüli önálló japanizálódási folyamatról beszélünk, akkor olyan újításokra és megnyilvánulásokra gondolhatunk, amelyek egyrészt az addigi kínai referenciákban nem szerepeltek, másrészt az addigi kínai ismereteket kritikákkal illetik, továbbá az európai koncepciók révén kialakult kevert irányzatot követő orvosi iskolák megjelenése is ehhez a gondolatrendszerhez tartozik. Ezek közül később az ún. $k o$ 'ihō 古医方 (,régi orvosi irányzatot követö irányzatot”), vagy a ranpō-igaku 蘭方医学 („holland stílusú orvoslás”) nyugati orvosi ismereteket követők irányzatát, valamint az ún. kanransecchu- $h a$ 漢蘭折衷派, a tradicionális kínai és európai koncepciókat követő eklektikus vonalat szükséges kiemelni. ${ }^{49} \mathrm{Ez}$ az a folyamat, amikor a kínai tradicionális gyógyászat ugyan tovább él, de valamelyest átalakul - mondhatni japanizálódik - és az általunk jól ismert kanpō-igaku 漢方医学 formájában fejlődik tovább.

A téma kutatása tekintetében ez egy fordulópont, mert a japán gyógyászatot megitélésünk szerint nem lehetséges egy egységként kezelni, hiszen párhuzamosan többféle irányzat fejlödését kell nyomon követnünk, melyeket egybemosni nem szerencsés. Ennek eredményeképpen jelen cikkben a tradicionális irány taglalásától eltekintünk, és inkább a külső hatások okozta változások mentén haladunk tovább, ezért a korábban taglalt legelső nagyobb periódust

45 Olyan japán kifejezések és szavak csoportja, amelyeket a kínai kultúra megjelenése előtti időszakban alkottak meg és használtak Japánban. (KJE 1998: 2696).

Kindaichi 1986: 21-24.

Erről bővebben lásd Takó 2017.

Erről bővebben lásd Zentai 2013.

49

Lásd bővebben Zentai 2015. 
az európaiak megjelenésével kapcsolatos két rövidebb periódussal folytatjuk tovább, amelyek tanulmányozásával kapcsolatban feltétlenül ki kell emelnünk Wolfgang Michel-Zaitsu kutatásainak eredményeit, valamint Inoue Kiyotsune és Shinmura Taku, Miyamoto Yoshio, valamint Aoki Toshiyuki tanulmányait, ${ }^{50}$ amelyek nagymértékben hozzájárultak ahhoz, hogy következő nagyobb periódus orvoslásáról reális képet kaphassunk. Ezek alapján elmondhatjuk, hogy az orvoslás, azon belül is a sebészet és az anatómia általánosságban az európai hódítók megjelenésével nagymértékủ változáson megy keresztül. Noha ez a két időszak sokkal rövidebb, mint a kínai gyógyászat dominanciáját mutató korábbi korszakok, mégis úgy gondoljuk, kiemelten fontos az orvostudomány fejlödését illetően ezen periódusokkal behatóbban foglalkozni. Inoue szerint ugyan a két periódust Japánban két különálló időszaknak tekintik, ${ }^{51}$ és japán nyelven elnevezésük is különböző, de ez az európai orvoslásban nem két különálló, hanem gyakorlatilag a XVI. és XVII. századi európai medicina egészét jelenti. Mindezek ellenére mi is a japán megközelítést követve két részben (II. periódus: portugál, spanyol hatás, III. periódus: holland hatás) taglaljuk az orvoslás további fejlődését.

\section{II. periódus: a portugál és spanyol hatás}

A XVI. századtól kezdve a portugálok és a spanyolok a kereszténység terjesztése, valamint az új technológiák, termények, és növények megismertetése mellett, az emberi test felépítésével foglalkozó írásokat is elhozták Japánba. Ezt az orvostudományt japánul nanban-igakunak 南蛮医学 („déli barbár” orvoslás) nevezzük. ${ }^{52}$ Eleinte sikeresnek bizonyult a kereszténység terjesztése, ennek kapcsán pedig több karitatív jellegü tevékenységről, intézmény létesítéséröl beszélhetünk. ${ }^{53} \mathrm{~A}$ kereszténység betiltása és üldözése révén viszont ez a folyamat hamarosan lezárul, és ilyen módon a nanban orvoslás elterjedése is félbeszakad. Az anatómia szempontjából viszont nagyon fontos ez az idöszak, ugyanis a japánok megismerkedhetnek a reális ábrázolásmóddal, vala-

\footnotetext{
50 Shinmura et al. 2006.

51 Inoue 1972: 517.

52 Az elnevezés onnan származik, hogy a japánok a korabeli portugálokat és spanyolokat, valamint az általuk meghódított környező ázsiai területeket (Goa, Fülöp-szigetek stb.) déli barbároknak nevezték. (Inoue 1972: 517).

53 Shinmura et al. 2006: 144.
} 
mint az európai sebészettel. A legelső dokumentált esemény Luis d'Almeida ${ }^{54}$ személyéhez kapcsolódik, aki engedélyt kapott Ōtomo Yoshishige 大友義鎮 (1530-1587) hadúrtól, hogy európai stílusú kórházat létesíthessen Ōita városban, ahol sebészetet folytatott. Később a kórház megsemmisült a Shimazuk és az Ōtomok közti hadakozás következtében ${ }^{55} \mathrm{~A}$ keresztény hittérítők által képviselt sebészet a keresztényüldözés ellenére a portugál származású Christovao Ferreira, ${ }^{56}$ valamint Kurisaki Dōki 栗崎道喜 ${ }^{57}$ révén még továbbfejlödött. A portugál és spanyol hatás különösen fontos volt a japán sebészet fejlödését illetően, ugyanis az új hadi technológiák okozta sérüléseket a sebészet nélkül nem lehetett volna gyógyítani. Ezek az újdonságok tehát hozzájárultak az új orvosi technikák megjelenéséhez.

Noha rövid periódusról beszélhetünk, láthatjuk, hogy mégis jelentős hatást gyakorolt a japán gyógyászat további fejlődésére, azon belül is a sebészet önálló kialakulására. Ugyanakkor elég, ha csak a karitatív jellegü létesítményekre, vagy arra szemléletre gondolunk, amely ehhez szorosan kapcsolódik. Ennek a fejlődési szakasznak a japán nyelvre tett befolyását sem szabad figyelmen kívül hagynunk. Mindemellett még nagyon fontos kapocsként is szolgált a japán orvosláson belül kialakult két nagyobb irányzat, a goseihō 後世方 és koihō 古医方 között. ${ }^{58}$ Ezt a periódust váltja fel közvetlenül az európai (a holland közvetítésnek köszönhetően „hollandnak” is mondott) orvostudomány megjelenése, amelyet a japán orvostörténetben kōmō-igakuként 紅毛医学 (,vörös hajúak orvoslása”) ismerünk. A hollandokkal létesített

54 Luis d'Almeida (1525-1583) gazdag portugál nemesi családból származott, sebészetet tanult. Apja révén jut el Goára, majd onnan Japánba. A kórház létesítéséhez saját vagyonát is felhasználta. (Inoue 1972: 520). Shinmura et al. 2006: 144.

56 Később zen-buddhista szerzetes lett és felvette a Sawano Chūan 沢野忠庵 japán nevet. (KJE 1998: 1099).

57 A fülöp-szigeteki Luzonban tanult sebészetet, és később megalapította a Kurisakiirányzatot. (KJE 1998: 789).

58 Nem sokkal az után, hogy a kínai orvosláson belül a XIV. században megjelent az ún. rishu-igaku 李朱医学, Japánban többek között Tashiro Sanki 田代三喜 (14651544), Manase Dōsan 曲直瀬道三 (1507-1594), Nagata Tokuhon 永田徳本 (?-?) révén válik ismertté. Az új ismereteiket saját tapasztalataikkal is kiegészítették, és így hozták létre a goseiho-irányzatot, amellyel ellentétben a régi gyökerekhez való ragaszkodást valló koihōirányzat igyekezett az orvosi tudás alapjait a régi kínai klasszikusokra, többek között a Shanghan Lunra helyezni, egyik legjelentősebb képviselője Nagoya Gen'i 名古屋玄医 (1628-1696). (Inoue 1972: 521). 
kapcsolat számos területen hozott újat a japán tudománytörténeten belül, mivel a holland nyelv a többi európai tudás közvetítő nyelve lett, így annak tanulmányozása különösen fontossá vált a japánok számára.

\section{III. periódus: a holland nyelv és tudomány hatása}

A hollandok nem sokkal a portugálok után érkeztek Japánba. Eredeti céljuk az volt, hogy erős kereskedelmi kapcsolatot létesítsenek a japánokkal, és mivel hittérítést nem szándékoztak végezni, ezért is kerülhettek kiváltságos helyzetbe a Tokugawa-kormányzás bezárkózási politikája alatt. Ehhez a helyzethez még az is hozzájárulhatott, hogy ebben az időszakban a japánok és a portugálok közötti diplomáciai kapcsolatok komolyan megromlottak, és a keresztényüldözés folyamata is elindult. Nagasaki (azon belül Dejima szigete) így válik az európai tudományok, ismeretek kapujává, és az európai tanulmányok fellegvárává azoknak a tolmácsoknak is köszönhetően, akik később nemcsak a nyelvi korlátok áthidalásában, hanem a különféle tudományok terjesztésében is rendkívül fontos szerepet játszottak azáltal, hogy rengeteg európai természettudományi, többek közt orvosi müvet fordítottak le japán nyelvre. Ök lettek a holland tudományok és a nyelv ismerői, vagyis japánul az ún. rangakusha-k 蕆学者. ${ }^{59}$ Ezzel egy időben számos orvos és tudós látogatott el Japánba, hogy megerősítsék a diplomáciai kapcsolatokat. Például, az Edokor első időszakában a német orvos, Caspar Schamberger (1623-1706) 1649ben látogatott el Japánba azzal a céllal, hogy bemutassa a nyugati orvosi újdonságokat és a hadtudomány vívmányait. Caspartól ezalatt több japán orvos is tanult sebészeti eljárásokat (amelyeket az orvostörténet Caspar-féle sebészetnek nevez), valamint ténylegesen gyógyított is főleg magas rangú japán személyeket. ${ }^{60}$ Ahogyan már korábban is utaltunk rá, rengeteg tolmács érkezett Dejimára, akik közül ki kell emelni Motoki Ryōi 本木良意 (1628-1697) és Narabayashi Chinzan 楢林鎮山 (1648-1711) nevét. Motoki nevéhez füződik a német Johann Remmelin eredetileg latin nyelven írt Pinax microcosmographicus címủ írásának fordítása hollandról japán nyelvre, amely Oranda Keiraku Kinmyaku Zōfuzu 阿蘭陀経絡筋脈蔵腑図解 címmel vált ismertté Japánban. Narabayashi szintén tolmácsként került a holland kereskedelmi

59 Egyik leghíresebb tudós köztük Ōtsuki Gentaku 大槻玄沢 (1757-1827), akinek a nevéhez füződik a Rangaku Kaitei 蘭学階梯 címü írás. Elérhető:

http://www.wul.waseda.ac.jp/kotenseki/html/bunko08/bunko08_e0077/index.html 
telepre, ahol aztán ő is elkezdett orvoslást tanulni. A kereskedelmi telepen tanultakat 1706-ban végül Köigekasōden 紅夷外科宗伝 címú írásában foglalta össze. Ezen felül Yoshio Kōgyū 吉雄耕牛 (1724-1800) nevét is fontos kiemelni, mert munkásságával hozzájárult a sebészeten kívül a belgyógyászat és a betegségek diagnosztizálásának fejlődéséhez. ${ }^{61}$

A holland kapcsolatoknak köszönhetően európai tudósok is megismerkedhettek a shinkyüjutsuval 銊尒術 (akupresszúrával és moxibúcióval történö stimulálás technikája), vagy a japán kámforral, valamint tanulmányozni kezdték Japán helyi sajátosságait, növény- és állatvilágát is, aminek eredményeképpen számos ilyen témájú írás is születik. Ennek egyik példája a német természettudós Engelbert Kaempfer (1651-1716) révén összeállított Nihonshi 日本誌 címü mủ is. Ugyanilyen fontos megemlíteni a német természettudós Philipp Franz von Siebold (1796-1866) nevét is, aki 1823-ban érkezett Japánba természettudományi és orvosi - azon belül föleg sebészeti - ismereteket oktatni. Sieboldnak Japánban született egy Kusumoto Ine 楠本イネ nevü leánygyermeke, akit Japán legelső nyugati stílusú gyógyászat orvosnőjének (szülész) tartanak. Hasonlóképpen, a bezárkózás politika ellenére, több japán tudós is eljutott Európába. A holland gyógyászat a japán anatómia önálló szakterületté válásában is óriási szerepet játszott, amelynek részletezésétől a jelen tanulmányban eltekintünk. ${ }^{62}$ Ahogyan már korábban is említésre került, ez az a fordulópont a gyógyászaton belül, amikor az orvoslás történetét már nem tudjuk egy egységként kezelni, mivel többféle irányzat ( $k o$ 'ihō, ranpōigaku, kanransecch ü, kanpō-igaku stb.) kezd párhuzamosan fejlődni. Ráadásul nemcsak irányzatokkal, hanem már önálló szakterületekkel találkozhatunk.

\section{Záró gondolatok}

Ahogy ezt tanulmányunk során megmutattuk, Japánban a történelem során az emberi test gyógyításának története és fejlődése párhuzamosan ment végbe materiális és spirituális vonalon. A tanulmány ezt a párhuzamos fejlődést volt hivatott bemutatni. A materiális és a spirituális megközelítés máig hangsúlyos szerepet kap Japánban, hiszen a klasszikus medicina mellett továbbra is virágoznak a különböző egyéb alternatív terápiák, ahogyan a spirituális támogatást kínáló módszerek is. Ahogy a múltban, úgy a jelenkorban is a spirituális megközelítés szorosan kapcsolódik a betegség lelki vonzatának kezelésé-

61 Shinmura et al. 2006: 149-150.

62 Erről bővebben Zentai 2015. 
hez. Japánban a modern orvostudomány fejlödésével nem vonultak vissza a spirituálisan gyógyító figurák, avagy hagyományos módszereket alkalmazó gyógyítók sem, hanem ezek a modern orvosi ellátással párhuzamosan, azt szinte kiegészítve tevékenykednek napjainkban is. Manapság egyre többen vagyunk annak tudatában nem csupán Japánban, hanem máshol is a világon, hogy valójában a holisztikus megközelítés kínálja a leghatékonyabb eredményt a gyógyításban. Ahogy azt Japán példája is mutatja, a különböző megközelítések gazdag hagyományukból táplálkozva tudnak egymás mellett, ideális esetben egymást kiegészítve létezni és müködni.

\section{Felhasznált irodalom}

Akata Mitsuo 赤田光男 1979. „Girei denshō 儀礼伝承 [Rítus és hagyomány].” In Akata Mitsuo 赤田光男, Miyata Noboru 宮田登, Fukuta Ajio 福田アジオ et al. (eds.) Nihon Minzokugaku 日本民俗学 [Japán néprajza]. Tokyo: Kōbundō, 83-112.

Birtalan, Ágnes 1993. „Scapulimancy and Purifying Ceremony (New Data on the Darqad Shamanism on the Basis of Materials Collected in 1992)." In Proceedings of the 35th PIAC September 12-17, 1992 Taipei, China. By Chieh-hsien Ch'en. Taipei, Taiwan, National Taiwan University and Center for Chinese Studies Materials, 1-10.

Birtalan, Ágnes 2006. „Initiation of Shaman-Type Mediators. Brief Survey of the Cases of Korean Mudang, Mongolian Böö and Hungarian Táltos.” In Hungary, Central and Eastern Europe and Korea. Current Issues in Humanities and Social Sciences 17th - 19th July 2006. (The Sixth International Conference of KACEEBS). Seoul, Korea, Hankuk University of Foreign Studies, 197-206.

Blacker, Carmen 1975. The Catalpa Bow: A Study of Shamanistic Practices in Japan. London: George Allen \& Unwin.

Csendom Andrea 2014. „A japán buraku társadalmi réteg kialakulása és gyökerei: A kegare félelem.” In Doma Petra, Takó Ferenc (szerk.) ,,Közel, s Távol” IV. Az Eötvös Collegium Orientalisztika Mühely éves konferenciájának elöadásaiból, 2014. Budapest: ELTE Eötvös Collegium, 403-424.

Fairchild, William P. 1962. „Shamanism in Japan.” Folklore Studies 21: 1-122.

Fujikawa Yū 富士川游 1904. Nihon igakushi 日本医学史 [Japán orvostörténet]. Tōkyō: Shōkabō.

Fujikawa Yū 富士川游 1933. Nihon igakushi kōyō 日本医学史綱要 [A japán orvostörténet lényege]. Tōkyō: Kokuseidō.

Hattori Toshirō 服部敏郎 1981. Nihon igakushi kenkyū yowa 日本医学史研究余話 [Japán orvostörténeti kutatások]. Tōkyō: Kagakushoin.

Hendry, Joy 1986. Becoming Japanese. The World of the Pre-School Child. Manchester: Manchester University Press.

Hoppál Mihály 2006. „A samanizmus kutatása Magyarországon.” Ethnographia 117: 345-367.

Hoppál, Mihály 2013. Shamans and Symbols. Prehistory of Semiotics in Rock Art. Budapest: International Society for Shamanistic Research. 
Iijima Yoshiharu 飯島吉晴 1991. Kodomo no minzokugaku. Kodomo wa doko kara kita $n o k a$ 子供の民俗学子供はどこから来たのか [A gyermek néprajza. Honnan érkeznek a gyermekek?]. Tokyo: Shinyōsha.

Inoue Kiyotsune 井上清恒 1972. „Nanban igaku no tenkai 南蛮医学の展開 [A déli barbár orvoslás fejlödése]." Shōwa Igakkai Zasshi 32.10. Tōkyō: The Showa University Society, 517-524.

Itabashi Haruo 板橋春夫 2007. Tanjō to shi no minzokugaku 誕生と死の民俗学 [A születés és halál néprajza]. Tokyo: Yoshikawa Kōbunkan.

Kalland, Arne 1991. „Facing the Spirits: Illness and Healing in a Japanese Community.” Nordic Institute of Asian Studies. NIAS Reports 2.

Kindaichi Haruhiko 金田一春彦 1986. Nihongo 日本語 [Japán nyelv]. Tōkyō: Iwanami Shoten.

Kiss Mónika 2017. „Szútrák a hosszú élethez Amoghavajra fordításában: A Fugen Enmei szútra kutatásának margójára.” Távol-keleti Tanulmányok 8.2: 87-126.

KJE = Shinmura Izuru 新村出. 1998. Kōjien 広辞苑 [Kifejezések erdeje] 5th edition. Tōkyō: Iwanami Shoten.

Kosoto Hiroshi 小曾戸洋 2002. Kanpō no rekishi 漢方の歴史 [A tradicionális japán gyógyászat története]. Tōkyō: Taishūkan.

Lebra, Takie Sugiyama 1976. Japanese Patterns of Behavior. Honolulu: University of Hawaii Press.

Maki Sachiko 橹佐知子 1999. Nihon no kodaiijutsu 日本の古代医術 [Japán ókori gyógyászata]. Tōkyō: Bungeishunjū.

Matsuoka Etsuko 松岡悦子 2003. „Ninshin, shussan. Ima, mukashi 娃娠、出産。今と昔 [Várandósság, születés. Ma és régen]. In Shintani Takanori 新谷尚紀, Namihira Emiko 波平恵美子, Yukawa Yōji 湯川洋司 (eds.) Kurashi no naka no minzokugaku 3. Isshō 暮らしの中の民俗学。3. 一生 [Folkór a mindennapi életben. 3. Életciklus].” Tokyo: Yoshikawa Kōbunkan, 9-34.

Mecsi Beatrix 2017. „A „Magányos szent” és a „Hegyi szellem” Korea buddhista kolostoraiban.” In Hamar Imre, Kósa Gábor, Gelle Zsóka (szerk.) Szent hegyek a buddhizmusban. Budapest: ELTE Buddhizmus-kutatás Központja, 149-159.

Miyata Noboru 宮田登 2007. Kodomo, rōjin to sei. Miyata Noboru Nihon wo kataru shirīzu 12. 子供、老人と性。宮田登日本を語るシリーズ [Gyerek, idős és nemi élet. Miyata Noboru Japánról mesél sorozata 12.].” Tokyo: Yoshikawa Kōbunkan.

Namihira Emiko 波平恵美子 2009. Kegareケガレ [Tisztátalanság.]. Kōdansha Gakujutsu Bunko.

Németh Anita 2018. „Pokol és Paradicsom kapuja: az Osorezan.” In Doma Petra, Takó Ferenc (szerk.) „Közel, s Távol” VI. Az Eötvös Collegium Orientalisztika Mühely éves konferenciájának elöadásaiból, 2016. Budapest: ELTE Eötvös Collegium, 83-106.

NKI=Nihon Tōyōigakkai 日本東洋医学会 (ed.) 2002. Nihon kanpōigaku 日本漢方医学 [A japán tradicionális orvoslás]. Tōkyō: Nihon Tōyōigakkai.

Ohnuki-Tierney, Emiko 1984. Illness and Culture in Contemporary Japan: An Anthropological View. Cambridge: Cambridge University Press.

Ōtō Yuki 大藤ゆき 1968. Koyarai 児やらい [Gyermeknevelés]. Tokyo: Iwasaki Bijutsusha. 
Ōtsuka Yasuo 大塚恭男 2002. Tōyōigaku 東洋医学 [Tradicionális keleti orvoslás]. Tōkyō: Iwanami Shoten.

Ōtsuki Gentaku 大槻玄沢. Rangaku Kaitei 蘭学階梯 [Bevezetés a holland tudományokba]. (s.n.).(s.l.). http://www.wul.waseda.ac.jp/kotenseki/html/bunko08/bunko08_e0077/index.html

Papp Melinda 2013. „A korai gyermekkor rítusai Japánban és a hozzákapcsolódó hagyományos népi hitvilág" Távol-keleti Tanulmányok 3.1-2: 227-248.

Papp, Melinda 2016. Shichigosan. Continuity and Change of a Family Ritual in Contemporary Urban Japan. New York: Palgrave Macmillan.

Papp Melinda 2018. „Tisztaság és tisztátalanság képzetei a japán népi kultúrában. A gyermekszületéshez kapcsolódó rítusok és tilalmak.” In Déri Balázs, Kósa Gábor, Vér Ádám (szerk.) Purum et immundum. Vallási elképzelések a tisztaságról és a tisztátalanságról. Az Eötvös Loránd Tudományegyetem Bölcsészettudományi Karán 2016. október 14-15én tartott vallástudományi konferencia elöadásai. (AГION könyvek 4.) Eötvös Loránd Tudományegyetem, Bölcsészettudományi Kar. Vallástudományi Központ, Budapest, 122-134.

Sakai Shizu 酒井シヅ 1982. Nihon no iryōshi 日本の医療史 [A japán gyógyászat története]. Tōkyō: Tōkyō Shoseki.

Shinmura Taku 新村拓 et al. 2006. Nihon iryōshi 日本医療史 [Japán orvostörténet]. Tōkyō: Yoshikawa Kōbunkan.

Shuzui Kenji 守随憲治 2000. Chikusai 竹斎 [Chikusai]. Tōkyō: Iwanami Shoten.

Szabó Balázs 2013. „Shushigaku - a Tokugawa Japán »hivatalos« filozófiája.” In: TávolKeleti Tanulmányok 2.1: 135-144.

Szabó Balázs 2016. Test és Tudat - a japán harcmüvészeti filozófia hajnala. Budapest: Torii Könyvkiadó.

Takó Ferenc 2017. „Fordítva: Nyugati társadalomfilozófiai koncepciók és terminusok »japanizációja« a korai Meiji érában.” Távol-keleti Tanulmányok 2017.2: 151-187.

Tanba Yasuyori 丹波康頼 1859. Ishinpō 医心方 [A leglényegesebb orvosi eljárások]. (n.p.). $\mathrm{http}: / /$ www.emuseum.jp/detail/100173/000/000?mode=detail\&d_lang=zh\&s_lang=zh\&cl ass $=\&$ title $=\& \mathrm{c} \_\mathrm{e}=\&$ region $=\&$ era $=\&$ century $=\&$ cptype $=\&$ owner $=\&$ pos $=65 \&$ num $=4$

Wang Shuhe 王叔和 1650. Mai jing 脈経 [Pulzus könyve]. (n.p.). https://rmda.kulib.kyoto-u.ac.jp/item/rb00005300\#? $=0 \& \mathrm{~m}=0 \& \mathrm{~s}=0 \& \mathrm{cv}=383 \& \mathrm{r}=0 \& \mathrm{xywh}=-$ $5214 \% 2 \mathrm{C}-240 \% 2 \mathrm{C} 16906 \% 2 \mathrm{C} 4800$.

Wolfgang, Michel-zaitsu 2000. "Inner Landscapes" - Japans Reception of Western Conceptions of the Body. Medicine in Japan and Germany. Bonn: Japan Society for the Promotion of Science / Deutsche Gesellschaft der JSPS-Stipendiaten.

Yamai no Sōshi 病草紙 [Betegségek képeskönyve]. (s.n).(s.1.). http://archive.wul.waseda.ac.jp/kosho/chi04/chi04_04420/chi04_04420.html

Zentai Judit Éva 2013. Az Edo-kori egészségmegörzés és orvoslás képe Kaibara Ekiken Jódzsókun címü irásának elemzése alapján. Forrástanulmány a japán orvoslás-történet kutatásához. Doktori disszertáció. Budapest: ELTE BTK Nyelvtudományi Doktori Iskola.

Zentai Judit Éva 2015. „A tradicionális kínai és az európai koncepciók egyidejü alkalmazása a japán orvostudományban és anatómiában." Kaleidoscope Müvelödéstudomány-és Orvostörténeti Folyóirat 11: 12-22. 